\title{
PUEBLOS DE SEVILLA EN ÉPOCA ISLÁMICA. BREVE RECORRIDO HISTÓRICO-POLÍTICO
}

\author{
José Ramírez del Río
}

\begin{abstract}
In this article we compile a short account of the news provided by the Arabic chronicles related to the history of the villages of Seville (Carmona, Alcala del Rio, Osuna...) in the Moorish period, focused mainly on politics. There is also a lot of information about the most important people who lived there. On the notes there is a bibliography of the works published about this subject in the last fifteen years, when closed study of the history of this period increased in a great measure.
\end{abstract}

El interés por la historia local en Andalucía ha ido en aumento en los últimos años de una manera extraordinaria. Si hace diez años los estudios sobre núcleos de población se centraban en ciudades de importancia, desde entonces la sucesión de congresos sobre poblaciones de menor tamaño ha sido una constante en la actividad académica ${ }^{1}$, así como la publicación de artículos sobre este tema en diversas revistas ${ }^{2}$. El creciente interés por la historia en los pueblos de nuestra provincia se ha plasmado, asimismo, en la proliferación de excavaciones arqueológicas. Éstas ya no pasan por los estratos de época islámica a toda prisa buscando llegar cuanto antes a los de época romana y tartésica, sino que reciben una atención cada vez mayor.

Este interés por la época andalusí choca en ocasiones con la dificultad de no disponer de noticias que podrían resultar muy relevantes a la hora de analizar los vestigios materiales, o incluso con el hecho de no disponer de traducciones adecuadas de algunos fragmentos de las crónicas que tratan este período, lo que provoca algunos errores $^{3}$. Incluso los artículos publicados sobre noticias de las fuentes árabes son de difícil acceso en muchas ocasiones, ya sea por el carácter local de las revistas en que se

\footnotetext{
${ }^{1}$ Véanse los sucesivos congresos sobre la historia de Alcalá de Guadaíra, de los que están ya publicadas las actas de los cinco primeros, y en prensa los del sexto, el de Osuna, publicado por la Universidad de Sevilla: J.J. Iglesias y M. García (eds): Osuna entre los tiempos medievales y modernos (s.XIII-XVIII), (Sevilla 1995), el de Écija o el recientemente celebrado I Congreso sobre Historia de Carmona.

${ }^{2}$ Cfr. M. Vera, "Morón durante el emirato", Mauror, 1 (1996), 1-12; M. Gordón Peral, "De la importancia de la atestiguación documental para el estudio de la toponimia. A propósito de Qal'at Ragwăl", Al-Qantara, XIII, 2 (1992), 349-365; J. Pascual Barea "De Mons Acvtvs al castillo de Cote (Hișn Aquaț), Archivo Hispalense, 1995.

${ }^{3}$ Como es el caso del ta tib y de la construcción de murallas con este impuesto en Sevilla, Córdoba o Niebla.
} 
publican ${ }^{4}$, ya por la limitada difusión que las actas de los congresos puedan tener. Por todo ello nos hemos animado a hacer una recopilación lo más exhaustiva posible sobre las noticias de carácter político relativas a los pueblos de Sevilla en las fuentes árabes, a lo que hemos añadido referencias bibliográficas sobre los estudios acerca de la época andalusí, lo que esperamos que sirva para facilitar la búsqueda de bibliografía tanto a estudiantes como investigadores que se acerquen a la materia.

Hemos de hacer dos precisiones sobre este trabajo; en primer lugar esta revisión de fuentes ha permitido encontrar textos nuevos que pueden ser de importancia, por lo que, aunque pueden no tener un gran valor en el contexto general, y la relevancia de estas poblaciones en el territorio, nos extendemos más en esos hechos, citando de pasada hechos más destacables para la historia de estas localidades pero que son ya tan conocidos que no merece la pena abundar en ellos. El otro aspecto que queremos destacar es la ausencia de referencias a los caminos que enlazaban unas poblaciones con otras. Esto no se debe en absoluto a una falta de interés por estas vías de comunicación, sino por el contrario, al deseo de tratarlos de forma más adecuada. En nuestra opinión éste es un asunto que se ha tratado de forma diacrónica: la mera descripción que nos dan los geógrafos árabes y en especial al-Idrisī, no es relevante para todo el período andalusí, y más teniendo en cuenta los grandes cambios que sufrieron las poblaciones que enlazaban. De unas vías herencia de la Antigüedad hasta las del s. XIII es necesario dedicarles un estudio más pormenorizado; lógicamente no son iguales las vías que unen Sevilla con Hișn Aqūt en el s. IX, en que éste era un núcleo fortificado rebelde, que las del s XII cuando la extracción de la cal de sus canteras era de gran utilidad para las construcciones de Sevilla. Tampoco serían iguales las comunicaciones entre Sevilla y Constantina en el s. IX que en el s. XII, cuando el hierro de sus minas era importante para la fabricación de armas en la capital almohade -como prueba el hecho de existir en Sevilla incluso un mercado de vendedores de flechas -. Por todo ello pensamos que es mejor dejar esta cuestión para una segunda parte de este artículo. Planteadas estas dos restricciones, pensamos que este artículo puede ser de utilidad, y puede ahorrar tiempo a otros muchos investigadores.

\footnotetext{
${ }^{4}$ Como sucede con algunos artículos publicados sobre el castillo de Cote, de bastante interés pero que no han recibido apenas atención.
} 


\section{Carmona $^{5}$ (Qarmūna).}

La ciudad de Carmona aparece con profusión en las fuentes árabes principalmente debido a su condición de núcleo urbano mejor fortificado de la zona. Sus murallas de época romana impresionaron tanto a los conquistadores, que al-Maqqari ${ }^{6}$ la cuenta entre las cuatro capitales del reino visigodo. Su incorporación al Islam se produjo en el año 712 , en que Mũsà b. Nușayr logró conquistarla, recurriendo a la astucia ${ }^{7}$. Las defensas de la ciudad no debieron sufrir grandes daños pues durante la rebelión de al'Alà b. Mugit (763d.C./ 146 H) contra el emir 'Abd al-Rahmān I la pugna por dominar Carmona condujo a la batalla decisiva ${ }^{8}$, con victoria para el emir de Córdoba. Durante el ataque normando contra Sevilla $(230 \mathrm{H} / 844$ d.C) el gobernador esta cora buscó refugio en Carmona ${ }^{9}$. Según al-Himyari su carácter de lugar fuerte de la zona fue aprovechado para instalar un arsenal tras aquellos hechos ${ }^{10}$. Este mismo autor nos ofrece la mejor descripción que se conserva en época árabe:

Está al pie de un monte y tiene una muralla de piedra...es inexpugnable por todos lados salvo por el oeste. La altura de la muralla es aquí de cuarenta piedras, unos cuarenta y tres codos. Hay en este muro una torre conocida como al-Ayamma, en la que se ponen las tiraderas en los combates. También hay una esquina en este muro en la que se tuerce hacia el noreste, una construcción llamada Samar Mala, en la que hay una torre para los guerreros. Bajo esta torre hay un prado verde que no se pierde ni se seca de ningún modo. Junto a este muro hay un foso muy profundo que data de la antigüedad y cuya tierra se apoya contra el muro. En el paño sur de la muralla hay una piedra grande, inaccesible y lisa como una pared, a la que apenas alcanza la vista su parte alta. El muro está construido sobre ella, y entre la roca y la muralla queda espacio para recoger la miel y cazar crías de pájaro en las grietas de esta roca. En el muro meridional hay una puerta conocida como Puerta de Yarni, por una alquería que

\footnotetext{
${ }^{5}$ Se celebró en Carmona un congreso cuyas actas publicó el ayuntamiento en 1998: Actas del I Congreso de Historia de Carmona, en las que varios artículos versaron sobre el período andalusí: R. Valencia "La Cora de Carmona (712-1247): Medio físico y humano", 22-45, Ahmad TahirI, "El esplendor de la Carmona islámica", 47-57; M.J., Viguera Molins, "Carmona en las épocas de Almorávides y Almohades", 59-76; M. Valor Piechotta, "Las defensas de Carmona", 597-635; A. Jiménez Martín, "La proa de la balsa de piedra o la Puerta de Sevilla en la Edad Media", 653-663. De este último autor hemos de mencionar también su obra La Puerta de Sevilla en Carmona, (Sevilla 1989).

${ }^{6}$ Al-Maqqari, Nafh al-Tibb,(Leyden 1967), 99.

${ }^{7}$ Ibn 'Idāri, Al-Bayân al-Mugrib, II, (1951), 13-4 y Ajbăr MaÝmãáa, (Beirut-El Cairo 1989), 24.

${ }^{8}$ Ibn 'Id̃ări, Al-Bayãn al-Mugrib, II, 51-52; Ajbăr Maýma'a, 94. Según el Bayăn la situación del emir llegó a ser desesperada, siendo sitiado muchos días en la ciudad.

${ }^{9}$ Ibn 'Iḍâri, Al-Bayān, II, 87-88.

${ }^{10}$ Al-Himyari, Kitäb Rawd al-Mi tăr en La Peninsule Iberique au Moyen Âge, (Leyden 1938), 158-9 del texto árabe y 190-1 de la traducción francesa.
} 
había frente a ella así llamada. La puerta de Córdoba estaba situada al este; había en ella una alcazaba y varias torres. La puerta de Calsena estaba entre el este y el noroeste, y había una salida fácil hacia Córdoba, mientras el camino que partía de la Puerta de Córdoba era abrupto y difícil. La puerta de Sevilla está al oeste; además de ésta hay hay una segunda puerta que da al interior de la ciudad a cincuenta pies. En la ciudad de Carmona hay una mezquita bien construida, con siete naves sostenidas por columnas de piedra. Hay un mercado el jueves, y en la ciudad hay baños... Cerca de Carmona hay una campiña amplia, apta para la siembra, y en ella hay muchas alquerías con agua en abundancia, fuentes y pozos.

Los vaivenes de la política sevillana se dejaron sentir en Carmona durante la crisis del emirato omeya: en el año 276 H/ 889 d.C. el rebelde 'Abd Allāh b. Haŷŷâŷy hizo salir de Carmona al gobernador omeya Muhammad b. 'Abd Allāh b. Bāzí, aunque al poco volvió la ciudad a la autoridad del emirato. Cuando su hermano Ibrāhīm b. Haŷŷâŷ creó un estado semiindependiente ( $286 \mathrm{H} / 900$ d.C) sus puntos de apoyo fueron Sevilla y Carmona, poniendo más cuidado incluso en mejorar las defensas de la segunda ${ }^{11}$. Al morir Ibrāhim, su hijo Muhammad heredó Carmona, que, tras muchas vicisitudes, entregó a 'Abd al-Rahmmān III, aunque la rebelión del gobernador de la plaza por cuenta de Muhammad, Habỉb b. 'Amrūs, obligó al cerco de la ciudad ${ }^{12}$, que volvió a quedar bajo la autoridad omeya el veinticinco de septiembre de 917/5 de rabi' II del 305.

Tras el hundimiento del califato de Córdoba se apoderaron de Carmona los Hammudíes, líderes del partido bereber en al-Andalus, pero Yahyà b. 'Alì b. Hammūd fue derrotado por una coalición de los Banū Birzāl y los sevillanos. Los birzālíes, también beréberes, se apoderaron de la ciudad, y dieron comienzo a un reino que incluía la propia Carmona, Écija, Osuna y el castillo de Almodóvar. La rivalidad con la taifa de Sevilla fue continua, hasta la toma final de Carmona por Isma'îl b. 'Abbād'13 (459 $\mathrm{H} / 1066-7$ d.C.). La suerte de la ciudad quedó unida a la de la taifa sevillana, por lo que al caer ésta en poder de los almorávides pasó a dominio norteafricano ${ }^{14}$ :

Y no había acabado el mencionado mes de safar (marzo de 1091) cuando los almorávides ya se habían apoderado de todo, y no le quedaba a Ibn 'Abbãd (alMútamid) sino Carmona y Sevilla..Se dirigió Sir b. Abu Bakr a Carmona, y la combatió hasta que la conquistó por asalto. Esto ocurró el sábado, al mediodía del diecisiete de rabi' I del año mencionado (17 de mayo de 1091).

\footnotetext{
${ }^{11}$ E. Lèvi-Provençal, Historia de la España musulmana, (Madrid, 1982), 233.

${ }^{12}$ Ibn Hayyān, Al-Muqtabas, V, (Madrid 1979), 90-2.

${ }^{13}$ Ibn 'Idāari, Al-Bayān, III, 189; Ibn al-Jațib, Kităb A'māl al-a lăm, (Beirut 1956), 137.

${ }^{14}$ Ibn Abi Zar', Al-Aniss al-Mutrib bi Rawḍ al-Qirțăs, (Beirut 1973), 154-5.
} 
Carmona mantuvo su preminencia en el territorio y después de Sevilla fue el principal bastión de los almorávides: hacia ella escaparon tras la toma de Sevilla por los almohades ${ }^{15}$ (12 ša 'bān del año 541/ 17 de enero de 1147). Sus proverbiales defensas le ahorraron los sufrimientos de las dos conquistas almohades de Sevilla, y sólo se integró en el nuevo imperio tras el pacto entre Ibn Gāniya, gobernador almohade de Córdoba y Carmona, y las autoridades almohades ( $543 \mathrm{H} /$ noviembre de 1143). Sin embargo esta fortuna no duró: las tropas del emir andalusí Ibn Hamūšk, que luchaba contra los almohades, ocuparon la ciudad, creando graves problemas al futuro califa Yūsuf Abū Ya'qūb ${ }^{16}$ (25 de rabi'I de 555 / 4 de abril de 1160). El hecho de que los enemigos de los almohades fueran extraños a la gente de Carmona facilitó el acuerdo entre las dos partes para la entrega de la ciudad, que volvió a dominio almohade el 10 de muharram de 557/ 30 de diciembre de 1161.

Durante el dominio almohade de la zona, la capitalidad de Sevilla hace que Carmona reciba relativamente poca atención de los cronistas, que nos informan de algunas algaras cristianas $^{17 .}$ La desaparición de los norteafricanos de la escena devolvió protagonismo a Carmona, sin el apoyo de la cual el emir al-Bãyî no aceptó ocupar el poder en Sevilla. Tras el juramento de fidelidad de Carmona, éste aceptó el ya ofrecido por Sevilla ${ }^{18}$.

De la misma forma que Mūsà b. Nușayr ocupó Carmona antes de lanzarse sobre Sevilla, Fernando III ocupó también la ciudad en $1247^{19}$. En las condiciones de la entrega se estableció que sus habitantes musulmanes pudieran seguir viviendo en la ciudad. Curiosamente una fuente árabe $e^{20}$ sitúa la conquista cristiana dos años después de la de Sevilla $(648 \mathrm{H})$; lo escueto de la noticia no permite saber si se refiere a una última entrega de fortificaciones o a una expulsión de habitantes.

Además de su importante contribución a la historia política de al-Andalus, Carmona fue cuna de algunos personajes destacados de la cultura andalusí. Especial atención dedican las fuentes árabes a Jațab b. Maslama b. Muhammad b. Sa'îd Abū-l-Mugira alIyadi $^{21}$ (294 H/ 906-7 d.C.- 372H/ 982-3 d.C.), que estudió con maestros destacados en Oriente, tanto en Egipto como en La Meca, y destacó en gramática y en lengua árabe, alcanzando fama en todo al-Andalus. Otra personalidad destacada fue 'Abd Allāh b. alWalid b. Sa'd, que viajó por todo Oriente estudiando, y residió bastante tiempo en

\footnotetext{
${ }^{15}$ Ibn Șăhib al-Ṣalä, Al-Mann bi-l-Imăma, (Beirut 1987), 90-1.

${ }^{16}$ Ibidem.

${ }^{17}$ Por ejemplo en el año 578/ 1182-3 d.C. Cfr. Ibn'Idāri, Al-Bayăn al-Mugrib, (Beirut 1985), 90-1.

${ }^{18}$ Idem, 296.

${ }^{19}$ Alfonso X, Primera Crónica General de España, (Madrid 1977), II, 754.

${ }^{20}$ Al-Dajira al-saniyya, (Rabat, 1972), 79.

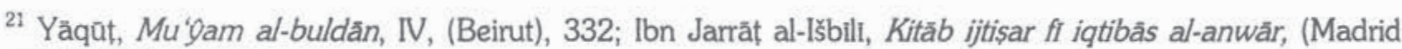
1990), 181.
} 
Egipto. Fue maestro de una generación de sabios de al-Andalus ${ }^{22}$ y murió en Siria en el año $448 \mathrm{H} / 1056$ d.C.

Écija (Istiŷŷa).

La historia de Écija $^{23}$ durante el dominio islámico fue particularmente conflictiva: fue una de las primeras ciudades atacadas por Tāriq tras su victoria en la batalla del Guadalete, y presentó una gran resistencia, ocasionando muchos muertos y heridos al ejército musulmán, que a la postre consiguió vencer a los habitantes de esta ciudad y a los refugiados del ejército visigodo, que se ocultaron tras sus fuertes murallas ${ }^{24}$, aunque el pacto entre Tāriq y la población, adornado de pormenores novelescos, evitó el asalto final ${ }^{25}$.

Durante la época del emirato fue capital de una cora o provincia, como la de Sevilla o Carmona ${ }^{26}$, que englobaba también a Osuna. Fue un territorio tan levantisco que las fuentes árabes recuerdan el dicho que circulaba por la capital ${ }^{27}$ : "Écija la inicua, mencionada con maldiciones y bochorno. Lo mejor, de ella se va. Lo peor, allí queda".

El motivo de esto es tanto la dura resistencia a Tāriq como la ayuda al rebelde muladí Ibn Hafșūn ${ }^{28}$, al que abrió sus puertas en el año 276 H / 889 d.C, y al que proporcionó la mayoría de los componentes del ejército con el que marchó contra Córdoba. La derrota de Poley frenó sus ambiciones (șafar 278/ mayo 891) y condujo a la vuelta de la ciudad a la obediencia del emirato. En el año 897 Ecija volvió a rebelarse a favor de Ibn Hafșun; el final de estos levantamientos llegó en época de 'Abd al-Rahmãn III, cuyo hāyỉib Badr b. A hmad tomó Écija ${ }^{29}$ el 19 de ŷumādà I del año 300/1 de enero de 913. Las murallas de la ciudad fueron derribadas, así como el puente sobre el Genil, que conectaba la ciudad con los dominios de Ibn Hafșūn. El puente, vital para la actividad de Écija, fue reconstruido por Almanzor, gastando grandes sumas ${ }^{30}$.

${ }^{22}$ F. Pons Boigues, Ensayo bio-bibliográfico sobre los historiadores y geógrafos arábigo-españoles, (Madrid 1898), 121.

${ }^{23}$ R. Valencia, "Los tenitorios de la cora de Écija en época árabe", Actas del I Congreso sobre Historia de Écija, (1989), 315-335.

${ }^{24}$ Ajbăr Maýmáa, (El Cairo-Beirut 1989), 19; Fath al-Andalus, (Madrid 1994), 21.

${ }^{25}$ Al-Maqqari, Nafh al-Tibb, I, (Leyden 1967), 163-4.

${ }^{26}$ Ibn Gălib,"Farḥat al-anfus", Magalla al-Majtatăt, (1955), 295; Al-Himyarı, Kitāb Rawḍ al-Míțār, 14-15 del texto árabe.

${ }^{27}$ Al-Himyari, Kitäb Rawḍ al-Mi tărr, 14.

${ }^{28}$ E. Lèvi-Provençal, Historia de la España musulmana, 237.

${ }^{29}$ Ibn Hayyăn, Al-Muqtabas, V, 54-56.

${ }^{30} \mathrm{Ibn}$ 'Idărì, Al-Bayăn al-Mugrib, II, 309. 
Tras el hundimiento del califato de Córdoba, Écija pasó a formar parte del reino taifa de Carmona, dominado por la dinastía beréber de los birzalíes, que englobaba además el castillo de Almodóvar y Osuna. El primer intento de la taifa de Sevilla de ocupar Écija concluyó con una severa derrota ${ }^{31}$ (5 de octubre de 1039) delante de la ciudad. Finalmente al-Mu'tadid, padre de al-Mu'tamid, tomó todo el territorio de la taifa ${ }^{32}$ en el año 459H/1066-7. En el año 1091 la taifa de Sevilla fue conquistada por los almorávides y esta ciudad compartió su suerte.

A pesar de esta turbulenta historia las fuentes árabes nos describen una ciudad próspera $^{33}$ :

La ciudad de Écija está junto al río de Granada llamado Genil, y es una ciudad hermosa que tiene un puente construido extraordinariamente, de piedra tallada. Tiene mercados prósperos y un comercio activo; tiene vergeles, huertos y jardines florecientes.

Las actividades principales eran el cultivo de trigo y cebada y la cría de ganado ${ }^{34}$, bastante rico, según las fuentes. La situación de Écija sobre el Genil no se aprovechaba sólo como punto de paso, también servía para su producción agrícola, pues sus molinos, muy numerosos, eran una de las principales fuentes de riqueza, y el historiador Ibn Hayyāan ${ }^{35}$ nos habla del daño que causó en ellos el desbordamiento del río en el año 235 H/ 849-50 d.C. Durante el dominio de almorávides (483 H/1091d.C. $-542-3 H / 1148$ d.C.) y almohades (542-3H/1048 d.C.- $625 \mathrm{H} / 1228$ d.C) Écija perdió protagonismo en el territorio, y aparece en las crónicas principalmente como presa de las incursiones de los enemigos de estos imperios en varias ocasiones: incursión de Alfonso I el Batallador ${ }^{36}(519-20 \mathrm{H} / 1126$ d.C.), ocupación de Ibn Hamūšk (554-7H/1160-2 d.C), como Carmona, a cuya suerte estuvo tan ligada Écija en época islámica, incursión de Alfonso VIII $^{37}$ (578H/ 1182d.C), particularmente violenta:

Luego fue a Écija y permaneció junto a ella hasta que hizo brecha en su muralla. Estuvo a punto de conquistarla; la guardaba Abü Muhammad b. Ta' Alla $h$ al-

\footnotetext{
31 Idem, III, 202-3. Traducción de F.Maillo en La caida del califato de Córdioba y los reinos de taifas, (Salamanca 1993), 172.

${ }^{32}$ I bn 'Iḍaril, Al-Bayān al-Mugrib, III, 202-3. Traducción en La caida del califato de Córdoba y los reinos de taifas, 234; Al-Marrakuši, Al-Mu'Q'ib, 68.

${ }^{33}$ Al-Idrisi, Kitāb nuzhat al-muštãq fi ijtirăq al-afăq, (Leyden 1968), 205-6.

${ }^{34} \mathrm{Ibn}$ Șăhịib al-Șală, Al-Mann bi-l-Imãma, 428-9.

${ }^{35}$ Ibn Hayyăn, Al-Muqtabis, (Beirut 1973), 5.

${ }^{36} \mathrm{Ibn}$ Simak, Al-Hulal al-mawšiyya, (Casablanca s.f) 94-5.

${ }^{37}$ Ibn 'Idārin, Bayā̃n al-Mugrib, (Casablanca 1985), 146.
} 
Kūmi. Dios le mantuvo en ella y fortaleció el valor de los musulmanes. Cuando llegó el jueves 13 de șafar (18 de junio) se apartó de Ecija y se dirigió a Sevilla.

El final de la época andalusí en Écija llegó en el año 1240, cuando los habitantes de la ciudad la entregaron a Fernando III con un acuerdo que les permitía mantener sus propiedades ${ }^{38}$.

Écija aportó bastantes hombres destacados a la historia de al-Andalus; los de más renombre en las fuentes árabes fueron Muhāb b. Idris ${ }^{39}$ (m. en 350H/ 961-2 d.C.), destacado en sintaxis, leyes y matemáticas, Abū 'Uțān Șa'id b. Nașr b. 'Umar b. Jalfūn $^{40}$, que estudió en La Meca y Bagdad, muriendo allí. 'Uțmān b. Mahāmis ${ }^{41}$ destacó en interpretación coránica y en historia, materia sobre la que escribió un libro. Tenía un cartel sobre la puerta de su casa que decía: "Uțmān, no seas ambicioso". Murió en el año 356 H/ 966-7 d.C. El estudio histórico fue cultivado también por otro ecijano, Isma'îl b. Ishāq b. al-Tahăn ${ }^{42}$, discípulo del famoso Qāsim b. Așbag, que escribió numerosas obras históricas, entre las que podemos citar su Libro sobre los hombres de Ecija. Este libro ejerció una notable influencia sobre Ibn al-Faradị, que incluyó gran cantidad de biografías de astigitanos: setenta y tres, que es muchísimo si lo comparamos con otras ciudades, como Sevilla, con setenta y tres personajes o Carmona, con siete. En el diccionario biobibliográfico que le siguió cronológicamente, la Sila de Ibn Baškuwăl, la cifras cambian de forma radical: Sevilla cuenta con ciento cuarenta y nueve, Écija con tres y Carmona con dos, lo que da una idea de la diferencia en el volumen de información de la que disponemos sobre cada época, y la dificultad que entraña enjuiciar la importancia relativa de cada población en el territorio partiendo de estas informaciones.

Morón (Mawrūr).

Morón ${ }^{43}$ tuvo bastante importancia en época islámica, en especial en tiempos del emirato dependiente de Damasco y en el de Córdoba. Fue conquistada por Mũsà b. Nuș ayr en el año 712 -3 d.C. y se asentaron allí árabes de la tribu de Ŷudam y beréberes Butr. El gobernador de al-Andalus Tuwāba b. Salama (128-9H/745-6 d.C) salió de

\footnotetext{
${ }^{38}$ Alfonso X, Primera Crónica General, t. II, 736.

${ }^{39}$ Ibn Jarrăt al-Išbili, Kitāb ijtişăr iqtibăs al-anwărr, (Madrid 1990), 173; Ibn al-Faraḍi, Ta'rij 'ulamā' alAndalus, biografía 135, (El Cairo-Beirut s.f).

${ }^{40}$ Ibn Jarrăț al-lšbili, Kitāb ljtișār fi qutibās al-anwär, 101; Al-Dabbl, Bugyat al-multamis, biografía 822; Ibn Baškuwāl, Al-Șila, biografía 458.

${ }^{41}$ F. Pons Boigues, Ensayo, 72; Al-Dabbi Bugyat al-multamis, biog. 1197; Ibn al-Faraḍi Ta'rij 'ulamã' alAndalus, biog. 899.

${ }^{42}$ F. Pons Boigues, Ensayo, p. 94; Ibn al-Faraḍı, Ta'rij 'ulamā' al-Andalus, biogr. 219.

43 M. Vera Reina, "Morón durante el emirato", Mauror, 1 (1996), 1-12. Es una buena recopilación de las noticias de época omeya, pero su hipótesis sobre el origen del topónimo Qalb no parece demasiado acertado, pues el grupo agnático al que hace alusión es el de los Kalbíes, y $\mathrm{K}$ es un fonema distinto de q en árabe. E mismo autor presentó en junio de 1998 su tesis doctoral sobre Morón en época islámica, pero aún está inédita; J. Pascual Barea, "El nombre latino y el origen de la ciudad de Morón", Desde la Frontera 6 (1993), 1-24.
} 
Morón para ocupar el gobierno de Córdoba, y cuando el gobierno quiso asegurar la situación de la zona recurrió a nombrar a dos omeyas para los gobiernos de Sevilla y Morón ${ }^{44}$ ('Abd Allāh b. 'Abd al-Malik, años 142-3 H/ 759-60 d.C.).

Morón era una cora (provincia) del emirato de Córdoba cuya importancia relativa se puede apreciar bien por la recaudación de impuestos en tiempos de al-Hakam I ${ }^{45}$ : Morón pagaba 21.000 dinares mientras Sevilla pagaba 35.099. No hay unanimidad acerca del emplazamiento de la capital de la cora: Lèvi-Provençal ${ }^{46}$ sugiere el castillo de Coripe y para J.Vallvée $e^{47}$ Qalb, nombre dado a la capital, tiene simplemente el significado de centro, corazón. Ibn Gãlib ${ }^{48}$ nos ofrece una descripción de la cora:

La cora de Morón limita con los términos de Carmona. Se encuentra al suroeste de Córdoba. Su ternitorio encierra muchos bienes y ha sido extraordinariamente favorecido. Tiene muchos olivos y árboles frutales, y es bueno cuanto brota de su tierra. Posee una llanura extensa y montañas elevadas e inaccesibles. Su capital es Qalb, a la que muy pocos pueden proteger y uno solo puede defender de una multitud.

Durante el emirato omeya la vida de Morón se desarrolló sin demasiada tranquilidad. Hubo un levantamiento de beréberes jāriŷ́ies, rápidamente reprimido en el año 200 H/815-6 d.C. durante el emirato de al-Hakam $\mathrm{I}^{49}$ :

En este año entró un beréber de los jarriyies en la provincia de Morón, en alAndalus, y con él iba una multitud. Llegó a alHakam el escrito del gobernador (de Morón) con la noticia. Esto preocupó a al-Hakam, que mandó llamar inmediatamente a uno de sus caídes, se lo contó en secreto y le dijo: "Ve inmediatamente contra el jàrỳí y tráeme su cabeza. Si no, tendré la tuya a cambio. Me sentaré aquí hasta que vuelvas".

El caíd fue contra el fàrì̀ y cuando se aproximó, preguntó por él. Le contaron que estaba en guardia y en una posición muy fuerte. Entonces el caíd recordó las palabras de al-Hakam: "Mátalo, si no, tendré tu cabeza a cambio". Se lanzó al ataque comiendo gran peligro, preparó una trampa con la que llegó hasta él, y lo mató, fue a presentar su cabeza a al-Hakam. Lo encontró en el mismo sitio en

\footnotetext{
${ }^{44}$ Ibn 'Idāri Al-Bayaann al-Mugrib, II, 49.

${ }^{45}$ Al-Himyarı, Kitāb Rawḍ al-Mi țār, 188 texto árabe; Al-Bakri, Kitāb al-Masălik wa-l-Mamālik, (Beirut 1968), 115-6.

${ }^{46}$ E. Lèvi-Provençal, La Peninsule Iberique au Moyen Age, 227.

47 J. Vallvé, La división administrativa de la España musulmana, (Madrid 1986), 324.

${ }^{48}$ Ibn Gălib, "Farhat al-anfus", traducción de J.Vallvé en La división administrativa de la España musulmana, 325.

${ }^{49}$ Ibn al-Atìr, Al-Kămil fi-l-ta'rij, VI , (Beirut 1965), 318-9.
} 
que lo había dejado, y había durado su ausencia cuatro días. Cuando (al-H akam) vió esto, felicitó al caíd, le tomó en consideración y aumentó su rango.

También durante el gobierno de al-Hakam I se produjo una revuelta importante, la de $\mathrm{Qa}^{\prime} \mathrm{nab}^{50}$, que hubo de huir a Mérida posteriormente, pero que se pudo mantener en el territorio hasta el reinado de 'Abd al-Rahmăn III. Intervinieron los habitantes de Morón en los conflictos de la cora de Sevilla, en que apoyaron a los muladíes, aunque con malos resultados. Durante la conflictiva época del emir 'Abd Allāh, Morón fue una constante preocupación para el emirato, destacando la figura de Tãlib b. Mawlūd, que reconstruyó las fortalezas de Aqūț y Ŷabal al-Hiŷara, desde las que hostigó a las tropas omeyas; la vuelta a la obediencia se produjo tras la conquista de la alcazaba por 'Abd al-Rahmañn III $^{51}$ en el año $312 \mathrm{H} / 924-5$ d.C.

A la caída del califato de Córdoba se formó en Morón un reino taifa dominado por los beréberes dammaríes ${ }^{52}$, bajo el mando de Nūh b. Abū Tuzirì ( 403 H/ 1013-4 d.C). La lucha contra la taifa de Sevilla en alianza con otras taifas bereberes fue una constante y el rey Muhammad 'Izz al-Dawla fue engañado y asesinado por al-Mu'tadid de Sevilla ${ }^{53}$. Su hijo Manãd 'Imad al-Dawla tuvo que entregar su reino a al-Mu'taḍị̣ en 458 H/ 1065-6 d.C, con lo que Morón siguió la suerte de Sevilla, siendo ocupada por los almorávides en el año 483-4 H/ 1091 d.C.

Morón cayó en manos de Fernando III hacia el año 637-8 H/ 1240 d.C., cerrando así su etapa andalus ${ }^{54}$. La conquista se produjo por el continuo hostigamiento a que sometió Rodríguez Galinado a la ciudad desde una torre situada en las cercanías, en un lugar denominado Margazamara (Marŷ al-tamara= Prado de los frutos); los habitantes prefirieron negociar su capitulación. Además del gobernador Tuwãba b. Salăma Morón dio a al-Andalus otros personajes de importancia ${ }^{55}$, como el poeta Umayya b. Gālib ${ }^{56}$ o el filólogo 'Abd ai-Salām b. al-Samah b. Nā'il b. 'Abd Allāh (m. 387 H/ 997-8 d.C.). La familia de los Banū Farqad ${ }^{57}$ dió algunas personalidades notables, sobre todo el poeta Abū Ishăq Ibrāhim b. Jalaf, y Muhammad b. 'Āmir b. Farqad $(563$ H/ 1167- 627 H/ 1229 d.C), que estudió con Averroes e Ibn Quzmān, y que escribió una obra bio-bibliográfica.

\footnotetext{
${ }^{50} \mathrm{Ibn}$ al-Qutiyya, Tárij iftitäh al-Andalus, 67 ed. y 53 trad.

${ }^{51}$ Crónica anónima del califa 'Abd al-Rahmaăn III al-Nășir, ed y trad. E. García Gómez y E. Lèvi-Provençal, Madrid-Granada, 1950, pp. 70 y 142.

${ }^{52}$ Ibn 'Iḍāri, Al-Bayãn al-Mugrib, III, 113. Traducción de F. Maillo en La caída del califato de Córdoba y los reinos de taifas, 103.

${ }^{53}$ Idem, 196.

${ }^{54}$ M. Benaboud, "La caída de Córdoba según las fuentes andalusíes", Actas del V Coloquio Internacional de Historia de Andalucía, (Córdoba 1988), 71-7; Alfonso X, Primera Crónica General, t. II, 740.

${ }^{55}$ Yãquat, Mứyam al-buldān, V, (Beirut s.f), 222.

${ }^{56}$ Poeta de la corte de Almanzor ; Cfr. Al-Mugrib fl] ulla-l-Magreb, t.I , 312.

${ }^{57}$ F. Pons Boigues, Ensayo, b. 275.
} 
Osuna (Ušūna).

Osuna $^{58}$ era un núcleo urbano de cierta entidad ya antes de la llegada de los musulmanes a la Península, y creció mucho en tamaño e importancia a lo largo de los primeros siglos de la historia andalusí: de ser una pequeña fortaleza pasó a ser una ciudad de tamaño medio ${ }^{59}$. Hay que destacar de este periodo el asentamiento de la tribu beréber $^{60}$ de los Banū Tarif, algunos de cuyos miembros tenían tendencias religiosas heterodoxas y que dieron origen a un clan, los Banū Sālim, que dió nombre a medina Sālim, la capital de la cora de Šadūna. Si para el geógrafo al-Idrīsĩ Osuna era capital de un distrito que abarcaba también a Lora, Ibn Hayyān ${ }^{61}$ nos habla de gobernadores de la cora de Osuna, por lo que parece que en el s.X la ciudad gozaba de la misma categoría administrativa que Sevilla, Écija y Carmona.

Tras la caída del califato de Córdoba Osuna quedó engiobada en la taifa de Carmona, gobernada por los beréberes Banū Birzāl ${ }^{62}$, hasta la anexión de esta taifa por la de Sevilla en el año 459 H/ 1066-67 d.C. Pasó pronto a dominio almorávide (483-4H/ 1091 d.C), y a juzgar por la descripción de esta guerra en el Kitäb Rawd al-Qirtās ${ }^{63}$ no parece que la ciudad sufriera grandes daños.

Como en muchos otros casos, el protagonismo de Sevilla en el territorio durante el dominio de almorávides y almohades oscureció el papel de Osuna en esta parte final de su periodo islámico. El emir Ibn Hūd, sucesor de los almohades tras su desaparición de alAndalus (hacia $625-6 \mathrm{H} / 1228 \mathrm{~d}$.C) fue incapaz de defender el territorio, y Osuna, uno de sus baluartes, se entregó a Fernando III en 124064. La última aparición de Osuna en fuente árabes se produce por el saqueo al que la sometieron los nazaríes granadinos al aprovechar en 1369 la guerra entre Enrique II y los partidarios del hijo del rey Pedro I, que se mantenían en Carmona ${ }^{65}$.

\footnotetext{
${ }^{58}$ R. Valencia, "La Osuna árabe", Osuna entre los tiempos medievales y modemos (s. XIII-XVIII), 13-26.

${ }^{59}$ Al-Idrisi, Kitäb nuzhat al-muštăq, 174 y 206 del texto árabe.

${ }^{60}$ Ibn Jaldūn apud E. Lèvi-Provençal, Historia de España musulmana, 52; Kitāb mafäjir al-barbar, en Tres textos árabes sobre beréberes en el Occidente islámico, (Madrid 1996), 248.

${ }^{61}$ Ibn Hayyăn, Al-Muqtabas, V, 253, en que se nombra a Dilhāł b. Muhammad gobernador de la cora. También en la p. 241 es nombrado Hamid b. Basil para el mismo cargo.

62 Vid. infra.

${ }^{63}$ Ibn Abi Zar', Al-Mutrib bi Rawḍ al-Qirtãs, 154-5. Al parecer sólo fueron sitiadas y asaltadas Sevilla y Carmona.

${ }^{64}$ M.J. Viguera, El retroceso territorial de Al-Andalus, (Madrid 1997), 113-119.

${ }^{65}$ Ibn al-Jațib, Ihăta, t. II, (El Cairo 1974), 90-1. Hay una traducción de este texto en el artículo de R. Valencia, 26.
} 
Varios personajes nacidos en Osuna alcanzaron relevancia en al-Andalus, entre ellos Saktān b. Marwãn b. Habīb b. Wãqif al-Mașmūdī ${ }^{66}$ (m. 346H/ 957-8 d.C.), experto en lengua y en leyes, y Abū-l-Qāsim Jalaf b. 'Abd Allāh b. Mudirir ${ }^{67}$ que llegó a ser predicador de la mezquita aljama de Córdoba y que enseñó ciencias durante bastante tiempo (m. 495 H/ 1101 d.C.).

San Juan de Aznalfarache.

En este municipio se encuentran las murallas del Hișn almohade construido por el califa al-Manșūr. Se ha debatido mucho acerca de la existencia de un Hișn de tiempos de al-Mu'tamid, por lo que creemos interesante ofrecer una nueva traducción de un texto procedente del Bayān al-Mugrib ${ }^{68}$ :

Llegó el año $589 H$ (1193 d.C.) y en él ordenó al-Manșür proyectar un alojamiento fuera de Sevilla que sirviera para albergar a los combatientes por la fe y para espantar a los infieles. Ordenó que estuviera en la cima del Aljarafe para que controlara la garganta del río, y para que fuera como la luna creciente entre el alba y la mañana. Se erigió en el más corto plazo la silueta de los muros, se adecuó el lugar de las casas y se terminó el alcázar grande, con su mirador elevado sobre Sevilla. No se distinguía desde el llano, y la vista no alcanzaba la cumbre. Estas construcciones fueron de lo más grande que hizo, y estaban por encima de sus esperanzas. Al-Manșūr desde la capital atendía sus noticias, y dirigía preguntas sobre lo que habían avanzado en la construcción, hasta que se le hizo acuciante el conocer sus características e inspeccionar la forma en que se estaba construyendo. Envió a un inspector, que llegó a él y le informó. El anhelo de al-Manșūr incrementó, y lo llamó Hişn al-Faray. Ya había antes de éste un hișn llamado asi en la provincia de Sevilla. Săln b. Sid dijo: ".. Y en el año 442 (1050-1 d.C) reconstuyó al-Mú tamid "ala Alla $h$ Hișn al-Farâ".

Hay que tener en cuenta que Hișn al-Faraŷ es una denominación para una fortaleza en un lugar elevado que se registra en otros lugares de al-Andalus ${ }^{69}$. Las fuentes que ofrecen noticias geográficas tienden a dar cuenta de esta tipo de semejanzas en la toponimia ${ }^{70}$, por lo que pensamos que el Hișn de al-Mu'tamid debe buscarse en otro emplazamiento.

Aznalfarache tenía dos funciones: por un lado la defensiva, enfatizada por el texto de Ibn 'Id̄arì. Con este Hișn lo que se propuso el califa al-Manșūr fue poner coto a las

\footnotetext{
${ }^{66}$ Al-Rušați, Kitäb iqtibās al-anwãr, (Madrid 1990), 15; Ibn al-Faraḍi, Ta'rij 'ulamā' al-Andalus, biografía 586, aunque esta fuente dice que nació en Šadana.

${ }^{67}$ F. Pons Boigues, Ensayo, 168.

${ }^{68}$ Ibn 'Idârî, Bayān al-Mugrib, 214-5.

${ }^{69}$ Cfr. Ibn Șāhịib al-Ṣalā, Al-Mann bi-l-Imāma, p. 316.

${ }^{70} \mathrm{Cfr}$. al-Himyari, Kitã b Raw al-Mi țar, 181., en que se refiere al topónimo Marchena en Almería y Sevilla.
} 
incursiones de los cristianos, sobre todo portugueses, por la zona. La otra es la de ciudad palatina, como podemos observar por las veces que alli residió el califa al-Manșūr ${ }^{71}$, que destacó del lugar "la hermosura de sus vistas y la pureza de su aire". Además eran de gran importancia en Hișn al-Faraŷ las cúpulas y los palacios ${ }^{72}$.

Durante el asedio de Sevilla esta fortificación no pudo ser conquistada como lo fueron las demás (Lora, Cantillana, Alcalá de Guadaira, Guillena...), lo que da idea de su fortaleza, y fue una constante fuente de preocupaciones para el ejército castellano. Su rendición fue pactada por Fernando III en el mismo tratado por el que conquistó Sevilla ${ }^{73}$, con el acuerdo de entregarla a los "arraeces Axacaf y Aben Choeb"; sin embargo estos dos personajes hubieron de irse a territorio musulmán, y el hecho de que en la Dajira saniyya $^{74}$ se nos señale la conquista de Hișn al-faraŷ dos años después de la de Sevilla quizá indique que los sitiados no aceptaron dicho compromiso y pactaron por su cuenta.

Alcalá de Guadaíra (Qal'at Yãàir).

Alcalá de Guadaíra ${ }^{75}$ tuvo durante la época islámica una función clara de protección en avance de Sevilla, como ya indica su propio nombre: Qal'a significa fortaleza en árabe. La debió conquistar para el Islam Mūsà b. Nușayr en los momentos previos a la conquista de Sevilla (93-4 H/ 712 d.C) y fue capital de uno de los distritos de la cora ${ }^{76}$ durante el emirato. Según una fuente tardía fue la capital de los Banū Haŷyâŷy durante la revuelta contra el emir de Córdoba, 'Abd Allāh. Ibn Jaldūn, cuya familia procedía de Sevilla, sostiene, como Ibn 'Idāri ${ }^{77}$, que entonces fue destruida. Sin embargo esto es poco probable, ya que el Guadaíra es el único río de la región con comiente lo bastante fuerte como para hacer funcionar molinos- aunque es posible que en parte del periodo andalusí hubiera también molinos en una zona próxima del Guadalquivir-, por lo que dejar algo así sin la defensa de una fortaleza, sobre todo en tiempos tan agitados, parece difícil. En losaños 556-8 H/ 1160-2 d.C. el gobernador almohade de Sevilla ${ }^{78}$, 'Abd Allăh b. Abì Hafș, se instaló allí para atacar Carmona, y al poco el califa Yūsuf Abū Ya'qūb emprendió grandes obras en la zona: primero ordenó nivelar el terreno y hacer una canalización de agua hasta Sevilla ${ }^{79}$ (los Caños de Carmona). Poco tiempo después el

\footnotetext{
${ }^{71}$ Ibn 'Iḍări, Al-Bayăn, 218,222 y 227-8.

${ }^{72 ،}$ Abd al-Wahịid al-Marrakušı, Al-Mu 'Yib fi taljis ajbăr al-Magreb, (Leyden 1881) 212-3.

${ }^{73}$ J. González, Repartimiento de Sevilla, (Madrid 1951), 213.

${ }^{74}$ Al-Dajira al-saniyya, 79.

${ }^{75}$ R. Valencia, "Alcalá de Guadaíra en la Alta Edad Media: La Historia de Qalat Chabir", Actas de las I Jornadas de Historia de Alcalá de Guadaíra, (1987), 31-43.

${ }^{76}$ R. Valencia, Sevilla musulmana hasta la caída del califato, 32-49.

${ }^{77}$ Ibn Jaldûn, 'Ibar, (1969), t II, 201.

${ }^{78}$ Ibn Șăhịib al-Șalā, Al-Mann bi-l-Imăma, 120.

${ }^{79}$ Idem, p. 337.
} 
mismo califa se instaló allí con el ejército y ordenó construir una fortaleza de grandes dimensiones para proteger aquella parte del campo de Sevilla.

Por entonces cambia el nombre de la fortaleza en la fuente a Hișn al-qal'a y desde entonces sufre el acoso de las algaras cristianas, por ejemplo la que en ŷumādà II del año $585 \mathrm{H}$ (julio-agosto de 1189) condujo el rey Alfonso VIII hasta Alcalá, acción que desencadenó una respuesta contundente del califa al-Manșūr, que venció al rey castellano en Alarcos cinco años después. Sin embargo los castellanos siguieron atacando esta fortaleza. En el año 643-4 H/ 1246 d.C., cuando Fernando III estaba preparando la ocupación de Sevilla, Alcalá se entregó a Ibn al-Ahmar, rey de Granada y vasallo de Castilla, y éste a su vez la cedió a Fernando III, terminando así su período andalusi ${ }^{80}$.

A pesar de su carácter militar Alcalá de Guadaira era un lugar agradable para vivir, por sus praderas y la abundancia de agua. Entre sus habitantes podemos destacar a 'Āmir b. Jaddūs ${ }^{81}$, que compuso un poema sobre su pueblo natal que figura en antologías de la poesía árabe.

Alcalá del Río (Qal'a Ra'wãq, Hișn Za'būqa o Ra'būqaa ${ }^{82}$ ).

Antiguo núcleo de población que debía su importancia al hecho de ser el último vado en el Guadalquivir antes de llegar a Sevilla ${ }^{83}$. Fue conquistada por Mũsà b. Nușayr ${ }^{84}$ en el año 93-94 H/ 712 d.C., y su estratégica posición fue de gran importancia en el desarrollo de los hechos acaecidos en la cora de Sevilla. En el año 147 H/ 764-5 d.C se refugió en Alcalá el rebelde al-'Alà b. Mugit al-Yahșubĩ ante el acoso del emir 'Abd al-Rahmän I, aurque pronto hubo de escapar hacia Carmona, donde fue derrotado y muerto. Pocos años después ( 150 H/ 767 d.C) Alcalá vuelve a ser utilizada por los partidarios de Sa'îd al-Yahșubi al-Mațari ${ }^{85}$ para enfrentarse al emir 'Abd al-Rahmän I volvió a sitiar Alcalá, y tras la muerte de Sa'id en combate, las dos partes acordaron la entrega de la fortaleza. Para asegurar su dominio en la zona, el emir destruyó la fortaleza, que, sin embargo, fue pronto reconstruida, pues durante el ataque normando a Sevilla del año 844 d.C. fue el punto más alto que alcanzaron éstos en el Guadalquivir, pero no lo tomaron ${ }^{86}$. Fue una de las fortalezas de los Banū Haŷŷaŷ durante su sublevación contra el emir 'Abd Allāh, y

\footnotetext{
${ }^{80}$ Alfonso X, Primera Crónica General, t. II, 748; Al-Dajira al-saniyya, 68.

${ }^{81} \mathrm{Ibn}$ Sa'id, Al-Mugrib fi hullà -l-Magrib, (El Cairo 1978), 291-2; R. Valencia traduce en su artículo un poema muy similar, extraido de otra fuente, y lo atribuye a Ibrăhim al-Zawwăli.

${ }^{82}$ M. D., Gordón Peral, "De la importancia de la atestiguación documental para el estudio de la toponimia. A propósito de Qal'at al-Ragwăl", Al-Qantara, XIII, 2 (1992), 349-365. En este artículo D. Gordón sostiene que entre la fortaleza de época omeya y la actual población hubo un cambio de emplazamiento.

${ }^{83}$ R. Valencia, Sevilla musulmana, 235-6.

${ }^{84}$ Fath al-Andalus, (Madrid 1994), 24; Una descripción anónima de Al-Andalus, (Madrid 1983), 109 de la traducción y 100 del texto.

${ }^{85} \mathrm{Ibn}$ al-Atîr, A/-Kãmil fi-l-Ta'rij, V, (Beirut 1965), 588.

${ }^{86} \mathrm{Ibn}$ al-Quțiyya, Ta'rij iftităh al-Andalus, (Beirut-El Cairo 1990), 80-1.
} 
al parecer fue por ello destruida ${ }^{87}$ por Muțarrif b. 'Abd Allāh. Un lugar de tanta importancia estratégica no podía, sin embargo, quedar yermo durante mucho tiempo, y una noticia del año $427 \mathrm{H} / 1035-6$ d.C. nos indica que los beréberes, en su ataque contra el reino taifa de Sevilla, ocuparon esta fortaleza en el mismo ataque en que tomaron Tocina y Triana $^{88}$. Este ataque debió ser particularmente destructivo, pues en la descripción de al-Andalus del geógrafo al-Idrisi ${ }^{89}$ no aparece Alcalá del Río. Debió quedar alguna población, pues en Sevilla había una puerta en la muralla de época almohade con su nombre, lo que indica la existencia de algún poblamiento. Dada su importancia al llegar la conquista cristiana y la estrategia almohade de construir defensas de avance en el territorio (Alcalá de Guadaira, Aznalfarache..) suponemos que Alcalá del Río fue reconstruida por los almohades en el $\mathrm{s}$. XII ${ }^{90}$

Sanlúcar la Mayor (Šalũqa).

Sanlúcar la Mayor fue una de las alquerías del Aljarafe, comarca de prosperidad muy ponderada por las fuentes árabes ${ }^{91}$ :

Es el más noble en terrenos de toda la tierra y el más generoso en suelo productivo. Está plantado de olivos que se mantienen siempre en su verdor y es bendecido con el producto de ellos, que no cambia de cualidades ni se corrompe. Abarca en tierras, a lo largo y a lo ancho, parasangas y parasangas. El excedente de producción de cada lugar es recogido y llevado por mar hasta Oriente. Su aceite conserva el brillo y el dulzor durante años, sin variar su sabor ni dejar huella en él la espera, por ser superior en propiedades su terreno a cualquier otro para producir aceite. Asimismo su miel se conserva largamente, sin ponerse arenosa, resistiendo con sus propiedades sin cambiar. También los frutos secos de sus higueras se conservan mucho tiempo.

Tenemos una mención de época andalusí, en que se narran sucesos ocurridos en Sanlúcar durante una incursión cristiana ${ }^{92}$ :

En el año 578 (1182-3 d.C) se produjeron en al-Andalus sucesos espantosos, entre ellos que una tropa a caballo de cristianos de la parte de Santarén y Lisboa

\footnotetext{
${ }^{87}$ Ibn Hayyăn, Al-Muqtabas, t. III, 81.

${ }^{88}$ Ibn 'Idãari, Al-Bayān al-Mugrib, III, 191. Trad. Felipe Maillo en La caída del califato de Córdoba y los reinos de taifas, 162.

${ }^{89} \mathrm{Cfr}$. al-Idrisi.

${ }^{90}$ Hipótesis ya sugerida por F. Hernández en "Ragwal y el itinerario de Muza de Algeciras a Mérida", A/Andalus, XXVI (1961), 150

${ }^{91}$ Al-Himyari, Kitāb Rawd al-Mi'țār, 18-22; al-'Ud̦ri, Nușuss 'an al-Andalus min Kitāb Tarși' al-ajbār, 95-96. Traducción de R.Valencia en "La cora de Sevilla en el Kităb Tarși ' al-ajbăr", Andalućá Islámica, IV-V, 115-6.

${ }^{92}$ Ibn 'Iḍări, Al-Bayãn al-Mugrib, 145.
} 
llegaron a la alquería de Šał qa en el Aljarafe, y la atacaron con mil caballeros y mil peones. Mataron a todos los musulmanes que encontraron y tomaron prisioneros y botín.

Fue una de las fortalezas del Aljarafe cuya entrega se pactó en el tratado por el que Fernando III conquistó Sevilla, y debía ser entregada a "los arreces Axacaf y Aben Choab" 93 , pero teniendo en cuenta que éstos pasaron pronto a teritorio musulmán, y que la Dajira al-saniyya nos informa de la conquista de Salūqa dos años después de la de Sevilla, hay que considerar que sus habitantes continuaron la resistencia mientras pudieron ${ }^{94}$.

Tras su conquista definitiva por los cristianos esta plaza hubo de soportar numerosos ataques de los Banū Marin ${ }^{95}$, que en el año 676 H/ 1277 devastaron los alrededores de la fortaleza, repitiendo en el $684 \mathrm{H} / 1285$. Ese mismo año se produjo un segundo ataque mucho más destructivo ${ }^{96}$ :

Cabalgó el califa con todas sus tropas de guerreros de infantería y caballería, fueron contra el in de Sakı qa y lo combatieron hasta que lo conquistaron con la espada. Mataron a sus hombres, capturaron a sus mujeres y se adueñaron de sus bienes.

Alcolea del Río (Al-Qulay'a).

Su nombre significa "fortaleza pequeña". Tuvo cierta importancia en época islámica, ya que era un lugar de paso en la ruta entre Sevilla y Córdoba, que tenía una actividad intensa ${ }^{97}$. Allí había un importante albergue para viajeros y pasó a manos de los cristianos en 637-8 H/124098. Sin embargo la referencia más importante que tenemos sobre Alcolea en fuentes árabes es posterior a su ocupación por los cristianos, y se refiere al ataque del sultán meriní Abū Yūsuf Ya'qūb del año 676 H/1277d.C, de consecuencias devastadoras según Ibn Abĩ Zar ${ }^{99}$ :

$Y$ conquistó el califa por la espada el hișn de Cantillana, el de Guillena y el de Alcolea. Mató a todos sus hombres y capturó a todas las mujeres y los niños, y saqueó sus bienes. Arruinó las fortificaciones y quemó sus casas.

\footnotetext{
${ }^{93}$ J. González, El repartimiento de Sevilla, 213.

${ }^{94}$ Al-Dajira al-saniyya, 79.

${ }^{95}$ Ibn Abi Zar', Kitāb Raw d al-Qirtās, 325-6, 342, 356.

${ }^{96}$ Ibidem, 356.

${ }^{97} \mathrm{Al}-\mathrm{Idr} \rrbracket_{s}$ I, Kit $\prod_{b}$ nuzhat al-mušt $\rrbracket_{q}$, pp. 196, 206, 208. Traducción de Lèvi-Provençal en pp. 254 y 256.

${ }^{98}$ M. Benaboud, "La caída de Córdoba según fuentes andalusíes", 71-7.

${ }^{99}$ Ibn Abi Zar', Kitāb Rawḍ al-Qirțās, (Rabat 1973), 325; Ibn Jaldūn, 'Ibar, t. IV, 86.
} 


\section{Coria del Río (Qaura).}

Coria tuvo bastante importancia en los primeros siglos de la historia de al-Andalus, debido a su emplazamiento, cercano a la desembocadura del Guadalquivir, por lo que guardaba las islas y las marismas. Durante el ataque de los normandos ( $230 \mathrm{H} / 844$ d.C) fue prácticamente destruida ${ }^{100}$ :

Amanecieron la mañana del lunes en el pueblo de Coria, donde les presentó combate la gente del castillo. Coria está de la ciudad de Sevilla a doce millas. Se enfrentaron y fueron derrotados los musulmanes la mañana del lunes 12 de muharram (29 de septiembre), muriendo gran número de ellos. Los normandos se quedaron en Coria el resto de aquel día.

Sin embargo Coria fue reconstruida, pues Kurayb b. Jaldūn ${ }^{101}$ se apoderó de Coria del Río durante la revuelta contra el emir 'Abd Allāh del año 276H/ 889 d.C.

La llegada de los imperios norteafricanos no mejoró la situación de Coria, pues Sanlúcar de Barrameda cobró por entonces importancia en la misión de guardar la desembocadura del Guadalquivir, por lo que apenas encontramos mención de Coria en esta etapa final de la época islámica de Sevilla; sin embargo parece que fue un periodo bastante própero, pues ${ }^{102}$ :

La gente coloca candiles a la orilla a lo largo de dos parasangas de edificios ininterrumpidos, lugares de recreo y torres, desde Cantillana hasta Coria.

Lo que da idea de la prosperidad y la población alcanzada en la zona.

Entre los habitantes de Coria durante su época islámica tenemos que destacar al jurista Abū 'Abd Allāh Muhammad b. Sa'îd b. Ahmad b. Zarqūn ${ }^{103}$, que enseñó durante bastante tiempo el texto fundamental de la escuela jurídica más importante de al-Andalus -la malikí- : al- Muwattà.

Aznalcázar (Họsn al-qașar).

$\mathrm{El}$ nombre actual del pueblo es de origen islámico, Hișn al-qașar, en dialecto andalusí Haşn al-qașar ${ }^{104}$ (= baluarte del alcázar). Durante la época del emirato no tuvo demasiado protagonismo en el territorio ${ }^{105}$ : era uno de los numerosos husșun del Aljarafe,

${ }^{100}$ Al-'Uduri, Nușūs 'an al-Andalus min Kitāb Tarsi' al-ajbã̃, 98-100. Traducción de R.Valencia en "La cora de Sevilla..", 121-7.

${ }^{101}$ Ibn Hayyān, Al-Muqtabas, CHE, XIX (1953), 162.

${ }^{102}$ Una descripión anónima de al-Andalus, p. 69 de la traducción.

${ }^{103}$ Yãquàt, Mư'yam al-buldăn, t. IV, 412.

${ }^{104} \mathrm{~F}$. Corriente, Arabe andalusí y lenguas romances, (Madrid 1992), 39-40.

${ }^{105}$ Cfr. Ibn Hayyăn, Al-Mugtabis, t. III, 82; al-Himyari, Kitāb Rawd al-Míțar, p. 58 del texto árabe y 73 de la traducción al francés. 
tan ponderado por las fuentes árabes ${ }^{106}$. No está demasiado claro si pertenecía a la cora de Sevilla ${ }^{107}$ o a la de Niebla. Las apariciones de Aznalcázar en fuentes árabes en los primeros siglos de al-Andalus son escasas, pero evidencian la importancia de esta localidad: en el año 477 H/1035-6 fue proclamado allí el califa Idris I b. Hammūd ${ }^{108}$.

Aznalcázar estuvo incluida en el reino taifa de Sevilla. A la llegada de los almohades fue una de las primeras ciudades de al-Andalus en unirse al nuevo imperio, ayudándoles con tropas, como las otras ciudades del este del país ${ }^{109}$ (541 H/ 1146 d.C.), en la conquista de Sevilla a los almorávides (1147 d.C.). Las buenas relaciones con el nuevo imperio se rompieron debido al intento de los gobernadores almohades de atacar a Yũsuf al-Bitruŷi ${ }^{110}$, señor de Niebla, al que apoyó esta población; sin embargo al-Bitruŷŷi aceptó la soberanía almohade ${ }^{111}$ definitivamente (muharram de $546 \mathrm{H} /$ abril de 1151 d.C). En época almohade Aznalcázar mantuvo su importancia y sabemos que algunas personas de importancia del imperio residieron alli ${ }^{12}$. Durante la última parte del dominio almohade del territorio, Aznalcázar sufrió dos males: las incursiones cristianas, que llevaron a una columna portuguesa a atacar la ciudad113 en el año $578 \mathrm{H} / 1182-3$ d.C., y las guerras internas entre las distintas facciones almohades. Aznalcázar fue ocupada por el rebelde al-Bayāsĩ y luego volvió a manos de Abū-l-'Alà, gobernador de Sevilla ${ }^{114}$, en el año $623 \mathrm{H} / 1226$ d.C.

Aznalcázar fue tomada por los cristianos en 1253, tras pertenecer por un breve tiempo al reino de Niebla de Ibn Maḥūz, cerrando así su época islámica.

Entre los personajes importantes que dio Aznalcázar a la cultura andalusí podemos destacar a Ibn Habib al-Qașri el filósofo ${ }^{115}$, que fue asesinado por uno de los últimos califas almohades y del que conservamos algunos poemas.

\footnotetext{
106 Vid infra.

${ }^{107}$ Ibn Sa'id, Al-Mugrib, t. I, 296; R. Valencia, Sevilla hasta la caida del califato, 200; Descripción anónima de al-Andalus, 66 de la traducción y 60 del texto árabe. En esta fuente se denomina a Aznalcazar medina ciudad-; F. Roldán Castro, Niebla musulmana, (Huelva 1993), 295.

${ }^{108}$ Ibn 'Idărin, Al-Bayăn,III, 91. Trad. F. Maillo en La caída del califato de Córdoba y los reinos de taifas, 162.

${ }^{109}$ Ibn Jaldūn, Ibar, t. Il, 185; Ibn 'Iḍãri, Bayãn al-Mugrib, 34.

${ }^{110} \mathrm{Ibn}$ Jaldūn, 'Ibar, t. Il, 186; Ibn 'Idărĭ, Bayăn al-Mugrib, 38.

${ }^{111}$ A. Huici Miranda, Historia política del imperio almohade, (Tetuán 1956), 160. F. Roldán Castro, Niebla musulmana, 295.

${ }^{112}$ M. Marín, "La vida cotidiana" en El retroceso territorial de al-Andalus, 402-3.

${ }^{113}$ Ibn 'Iḍărì, Bayān al-Mugrib, 145.

${ }^{114}$ Idem, 273.

${ }^{115}$ Ibn Sa'id, Al-Mugrib, t. I, 296.
} 
Cantillana (Qaținyāna).

Cantillana fue un Hișn en época islámica y guardaba uno de los vados del río (majāda) en la activa ruta de Sevilla a Córdoba ${ }^{116}$. Debió tener especial importancia en época almohade $e^{117}$, en que se comenta como punto importante en el transporte de tropas hacia Córdoba. Fue conquistada por Fernando III en 1247 tras una durísima resistencia ${ }^{118}$, y las fuentes nos dicen que en el momento de su conquista guarecían la plaza setecientos guerreros musulmanes. Fue donada a las ordenes militares, que la cambiaron en época de Alfonso X (1253) por Moguer y Montemolín ${ }^{119}$. Cantillana aparece aún una vez en las fuentes árabes, con motivo de su destrucción total por el sultán meriní Abū Yūsuf Ya'qūb120 en el año 676 H/1277 d.C. Hacia el año 1307 aún no se había recuperado de este desastre.

Marchena (Maršāna).

Ciudad de cierta importancia en época islámica, como muestra el hecho de que alBakri ${ }^{121}$ la ponga junto a Córdoba, Carmona o Niebla en la sexta demarcación de la división de Hispania por Constantino. Al-Himyari ${ }^{122}$ la sitúa en la cora de Sevilla, pero la mayoría de las fuentes la incluyen en la de Carmona ${ }^{123}$. Parece que era una ciudad próspera $^{124}$ :

Ea en su término villas e castillos, de los cuales es Marchena, que es muy buena villa e poblada de gentes.

En época omeya la vida de esta población debió ser bastante tranquila, pues sólo conservamos noticias rutinarias, tales como la sustitución ${ }^{125}$ del gobernador Abü-l-Hakam por Ibn Mu'ammal o movimientos de tropas del gobierno ${ }^{126}$, lo que indica que permaneció leal a Córdoba durante la crisis del emirato de 'Abd Allāh.

\footnotetext{
${ }^{116}$ Al-Idrisi, Kitäb nuzhat al-muštăg, 196 del texto árabe y 254 de la traducción al francés.

${ }^{117}$ Ibn Şăhib al-Șală, Al-Mann bi-l-Imãma, 429.

${ }^{118}$ Alfonso X, Primera Crónica General, (Madrid 1955), t. II, 749; Al-Dajira al-saniyya, 70.

${ }^{119}$ F. Roldán Castro, Niebla musulmana, 76.

${ }^{120}$ Ibn Abi Zar', Kitäb Rawḍ al-Qirtăs, 325; Ibn Jaldūn, 'Ibar, t. IV, 86.

${ }^{121}$ Al-Bakri, Kitāb al-masălik wa-l-mamălik, 63.

${ }^{122}$ Al-Himyari, Kitāb Rawd al-Míțăr, 181 del texto árabe.

${ }^{123}$ Al-Răzi, Crónica del moro Rasis, p. 306; Ibn Gălib, Farhat al-anfus, p. 292; Yăquat, Mu'Ygam al-buldān, t. V, p. 107.

${ }^{124}$ Al-Razi, Crónica del moro Rasis, 306.

${ }^{125}$ Ibn Hayyān, Al-Muqtabas, V, 181.

${ }^{126}$ Ibn Hayyăn, Al-Muqtabas, III, CHE, XXVII (1958),168.
} 
Durante la época de taifas corrió la misma suerte que Carmona, y como el resto de la taifa de los birzalíes pasó a manos de los 'abbadíes de Sevilla en el año 1056 d.C. En el año 1091 pasó a dominio almorávide.

Marchena se entregó por pacto al rey rey Fernando III en 1240, junto con muchas otras poblaciones ${ }^{127}$. La última mención a Marchena en fuentes árabes hace referencia al saqueo de la ciudad por los granadinos, que en 1369 la asaltaron, y sólo se salvó de esta incursión la alcazaba ${ }^{128}$.

Entre los personajes destacados procedentes de Marchena podemos destacar a Ah mad b. Sayyed al-Jabir b. Dawd b. Abi Dawd (m. 376 H/), al que se describe elogiosamente una fuente oriental ${ }^{129}$.

Estepa (Isțabba).

Estepa estaba incluida en la cora de Šadūna ${ }^{130}$ según al-Himyari, que la califica de ciudad, o en la de Rayyo ${ }^{131}$ según la Crónica anónima, que describe así el territorio de esta cora:

Entre sus castillos y ciudades se cuentan Marbella, Fuengirola, Cártama, Comares, Vélez, Málaga, Coín, Alhama, Antequera y Estepa; todos ellos son castillos inaccesibles que producen grandes cantidades de higos, aceitunas, almendras, uvas y granadas.

Su carácter de lugar fortificado lo podemos constatar en las apariciones de Estepa en las crónicas árabes: en el año 276 H/889, Ibn Hafșunn, aliado con Awšaya de Ronda, conquistó la plaza ${ }^{132}$, y para mantener su dominio combatió varias veces con generales del emir de Córdoba ${ }^{133}$. Volvió a ser conquistada para los omeyas en época de 'Abd alRahmmān III $^{134}$, que desmanteló todas las fortalezas de la cora de Rayyo, pero la de Estepa fue reconstruida, pues su posesión fue uno de los aspectos más conflictivos en los tratados de paz entre las taifas de Sevilla -regida por al-Mu'tamid- y Granada -regida por 'Abd

\footnotetext{
${ }^{127}$ Alfonso X, Primera Crónica General, t. II, 740.

${ }^{128}$ Ibn al-Jațib, Ihăța, t. II, 90-91. Hay una traducción del texto en el artículo de R. Valencia "Osuna en los tiempos medievales y modernos", 26.

${ }^{129}$ Yăquat, Mư'gam al-buldān, t. V, 107.

${ }^{130}$ Al-Himyari, Kitāb Rawḍ al-Mítār, 23 del texto árabe.

${ }^{131}$ Crónica anónima, t. II, 60.

${ }^{132}$ Ibn Hayyã̃n, Al-Muqtabis, III, CHE, XVII (1952), 156.

${ }^{133}$ Ibn al-Quțiyya, Ta'rij iftităh al-Andalus, (Madrid 1926), t. II, 94 de la traducción y 110 de la edición.

${ }^{134}$ Ibn Hayyān, Al-Muqtabas, V, 220; La crónica de 'Arib sobre al-Andalus, 220.
} 
Allāh b. Buluqqin-, ya que había sido conquistada en la guerra entre ambos por el caíd granadino Kabbāb. Volvió a dominio sevillano ${ }^{135}$.

De la entidad de Estepa en época andalusí da idea el hecho de que al-Maqqari ${ }^{136}$, al hablar de los gobiernos de Córdoba, la cita junto a ciudades de la importancia de Ecija, Ronda o Cabra. Ibn Sa'îd nos informa de la existencia de una obra acerca de los literatos de este pueblo ${ }^{137}$.

Estepa cayó en manos de Fernando III en 1240, momento en que sus habitantes pactaron con el rey la entrega del pueblo ${ }^{138}$

Lora del Río (Lūra).

Esta población aparece ya en los primeros momentos de la conquista ${ }^{139}$-Mũsà b. Nu șayr pasó por allí tras ocupar Toledo-. Tenía bastante importancia estratégica, y cuando los omeyas atacaron el reino independiente creado por Ibn Haŷŷây, la conquistaron Muh ammad b. Ibrāhỉm y Qãsim b. Walìd. Desde Lora el caíd Ŷamil b. 'Uqba ejerció una presión sobre los rebeldes que los forzó a capitular ${ }^{140}$ (301 H/913-4 d.C.). Según al-Idrisí era uno de los hișn más importantes en la activa ruta entre Córdoba y Sevilla ${ }^{141}$, y dependía administrativamente de Osuna. Fue perdiendo importancia progresivamente ante el Hișn de Šantafila (Setefilla), a catorce Km. de la actual Lora del Río. Erigido por los Banū-l-Layt, de los beréberes zanata ${ }^{142}$, tenía una situación estratégica tan fuerte que Alfonso VIII, durante su incursión en el año $578 \mathrm{H} / 1182$ d.C. conquistó la plaza, y dijo ${ }^{143}$ : "Tras esta conquista caerán Sevilla y Córdoba". Dejó la fortaleza provista de defensores y provisiones, para tener una fortificación en el corazón de al-Andalus, pero los almohades recobraron la fortaleza dos años después144.

\footnotetext{
135 'Abd Allāh b. Buluqqin, El siglo XI en primera persona, (Madrid 1970), 161.

${ }^{136}$ Al-Maqqari, Nafh al-Tibb, t. I, 165.

${ }^{137}$ Ibn Sa'îd al-Magribi, Al-Mugrib fi hullà -1-Magrib, I, 35.

${ }^{138}$ Alfonso X, Primera Crónica General, t. II, 740.

${ }^{139}$ P. Chalmeta, Invasión e islamización, (Madrid 1994), 185.

${ }^{140}$ Ibn Hayyăn, Al-Muqtabas, V, 71-74 y 76.

${ }^{141}$ Al-Idrisì, Kitāb nuzhat al-muštăq, 196, 206 y 208.

${ }^{142}$ Al-Idrīisi, Kitāb nuzhat al-muštāq, 207 de la edición y 255 de la traducción; Ibn Hazm, Ŷamhara, 499; Al'Udri, Nușus 'an al-Andalus, 106.

${ }^{143}$ Ibn 'Iḍāri, Al-Bayăn, II, (Tetuán 1953), 43.

${ }^{144}$ Ibn Abì Zar',Kitāb Rawḍ al-Qirțās, 268.
} 
Durante la conquista del valle del Guadalquivir por Fernando III, Setefilla se incorporó pronto al reino castellano, pues en 1240 pactaron sus habitantes su entrega con el rey ${ }^{145}$. Lora del Río fue conquistada en 1247 , tras una breve resistencia ${ }^{146}$.

Con la conquista del valle por los castellanos no acaban las apariciones de este territorio en las fuentes árabes. En un texto de al-Qabtawri podemos ver la razón que llevó al despoblamiento de Setefilla, que hasta ahora se venía explicando por la falta de agua que padecían los habitantes de esta fortaleza:

Al alejarse (el sultán meriní) de Sevilla, asedió el Hișn de Guillena, y se apoderó de él el mismo día. Cumplió el pacto que había convenido a los prisioneros (que quedaban) vivos de enviarlos con su gente. Luego se trasladó al Hișn de Cantillana, en donde entró a espada tras un combate encarnizado, y entonces hizo probar a los enemigos de Dios todos los males. Echó de su alcazaba, a quien se había refugiado en ella, a la condición de presos, después de que alcanzaron en el combate -si esto les era útil- la mejor excusa. Tras esto fue hacia una fortaleza que había entre Lora y Constantina difícil de conseguir. En ella estaban los impios ifrayriyan, orgullosos y sin freno. Se enfrentó a ellos y los sitió. Éstos dijeron: "Largo de aquí. No somos como aquellos a los que os habéis enfrentado". "Nos encontraremos en el combate para humillaros por nuestras manos" "Somos los leones de los cristianos, como no hay otros en nuestro rio", y se prepararon para bajar a combatir y se dispusieron a pelear de la mejor manera posible. Se cumplió la orden yusufi de combatir con ferocidad, y lo hicieron (los Bañ̄ Marnn). Ordenó que no encontrara un musulmán a un infiel, en la victoria sobre ellos, que no lo atravesara y lo desgarrara con el filo de la espada. Los enemigos de Dios se esforzaron en la defensa, pero encontraron una fuerza como no la habían encontrado antes. Dios permitió y concedió la conquista de este in, y favoreció al Islam con la muerte de los que estaban en él. Había cerca de cuatrocientos combatientes ifrayriyan, de los que hubo diez que recibieron gracia. $Y$ fue su conquista, y la de Cantillana antes de ésta, signos claros que engrandecen, ante el que los contempla, la magnificencia de esta expedición ${ }^{147}$.

Entre los habitantes de Lora en época islámica podemos mencionar al poeta 'Abd alGaffär b. Mulih, del que apenas se conservan unos versos:

Pasamos la noche mientras el frío tejía el manto de la oscuridad

"Y lo rompieron nuestras claras copas

\footnotetext{
${ }^{145}$ Alfonso X, Primera Crónica General, t. II, 740.

${ }^{146}$ Ibidem, 749.

${ }^{147}$ Al-Qabtawri, Rasāill diwāniya min Sabta, (Rabat 1979), 61-62. Trad. J. Ramírez del Río.Esto se produjo durante la campaña del año 1277 y los ifrayriyun=los frailes, o miembros de órdenes militares. En este caso se trataba de la orden de San Juan.
} 
El río, como un enamorado, se quejaba de su alejamiento del jardín

y verías que en él había dejado su huella" ${ }^{148}$.

Lebrija (Nebriša).

Lebrija no aparece demasiado en las fuentes árabes, pero las referencias indican su carácter fortificado. Pertenecía a la cora de Šadūna (Sidonia), y durante la sublevación de Sevilla, que condujo a la creación del efímero reino de los Banū Haŷyâây, éstos intentaron extender su autoridad a la ciudad de al-Jawr, junto a Lebrija, sin éxito, pues la defendió el rebelde Sulaymān b. 'Abd al-Malik, que la había reconstruido, aunque lograron ocupar la misma cabecera de la zona (276 H/ 889 d.C.). Poco después ( 282 H/ 895 d.C.) las tropas del emirato, con el príncipe al-Muțarif a la cabeza, conquistaron la fortaleza a Sulaymān b. 'Abd al-Malik, y el castigo fue mucho más duro ${ }^{149}$ :

Con el mismo ritmo continuó su avance hasta Lebrija, la fortaleza de Sulaymān b. Muhammad b. 'Abd al-Malik. A su arribo la atacó Ahmad b. Hásim con catapultas, mató a mucha gente, rechazó a los defensores de la entrada y les obligó a guarecerse en el castillo. Entonces, viendo que el lugar y sus inmediaciones se hallaban libres de enemigos, aprovechó el ejército para lanzarse a la destrucción, incendiando, junto a las otras casas, la mezquita y las sementeras. Tampoco se salvaron las granjas ni las huertas de la devastación.

De este modo siguió el ejército su obra y, al ver que los defensores de la fortaleza eran incapaces de continuar la resistencia, tomó por asalto el castillo. El desbande de los asediados fue total y los insurrectos fugaron en distintas direcciones. Los que lograron escapar fueron acuchillados tras una persecución tenaz. De los que fueron apresados dentro de la fortaleza, se escogieron veinticinco cabecillas, cuya decapitación ordenó al-Mutamif. Una vez en posesión de la alcazaba, la fortificó y la confió a una guarnición de la fuerza leal, introduciendo en ella muchas mejoras.

Guillena (Ŷalyāna o Galyāna).

Las noticias de fuentes árabes sobre esta población son muy tardías. Sin duda fue uno de los baluartes que los almohades erigieron como defensa de avance en el territorio, y fue conquistada en 1247 durante las operaciones previas al cerco de Sevilla. Fue aprovechado por los cristianos con el mismo fin. Sufrió un durísimo golpe a manos de los Banū Marīn ${ }^{150}$ :

\footnotetext{
${ }^{148}$ Ibn Sa'id al-Magribi, Al-Mugrib fi hullà -I-Magrib, t. I, 298.

${ }^{149}$ Ibn Hayyăn, Al-Muqtabas, CHE, XXV-XXVI (1957), 340.

${ }^{150}$ Ibn Abi Zar', Kitäb Raw ḍ al-Qirțâs, 325; Ibn Jaldun, 'Ibar, t. IV, 86.
} 
$Y$ conquistó el califa por la espada el in de Cantillana, el de Guillena y el de Alcolea. Mató a todos sus hombres y capturó a todas las mujeres y a los niños, y saqueó sus bienes. Amuinó sus fortificaciones y quemó sus casas.

Constantina (Qustantiniyya).

Las menciones a Constantina en fuentes árabes son muy uniformes tanto en lo referente a la situación administrativa como a la terminología utilizada en la mayoría de los casos. Pertenecía al territorio de Firriš, Castillo de Hierro ${ }^{151}$ o Cerro de Hierro, pero no sabemos si el territorio de Firriš formaba una cora ${ }^{152}$ o era parte de otra de grandes dimensiones junto al territorio de Fahș al-Ballüt ${ }^{153}$ Al menos durante gran parte del $\mathrm{s} . \mathrm{X}$ debieron formar una unidad administrativa, pues en šawwäl del año 322 (septiembreoctubre de 934) fue nombrado 'Abd al-Rahmãn b. Muhammad b. al-Nazzam como gobernador de Firriš, Fahș al-Ballüt, Laqant, Miknasa y B.t.r.l.s. ${ }^{154}$. Las mismas dificultades encontramos para definir la condición de Firrǐ̌ y de Constantina, pues mientras para al-Maqqari ${ }^{155}$ Firriš era una ciudad, para al-Idrisi ${ }^{156}$ era un Hișn, y alHimyari ${ }^{157}$ sólo lo nombra como lugar (mawdu'). Estas dos últimas fuentes son las que nos proporcionan las informaciones más importantes sobre Constantina:

Entre Finiš y Córdoba hay dos jomadas de marcha. En ella hay una alquería conocida como Constantina, que era una gran ciudad de antigua fundación y en la que hay restos de iglesias. Se dice que fue construida en los días de Constantino, rey de los Rüm. Entre ella y Córdoba hay cuarenta millas ${ }^{158}$.

De alli hasta Constantina de Hierro hay dieciseis millas. Éste es un hisn importante, próspero y rodeado de montañas en las que hay minas de hierro, sobre cuya calidad y abundancia está todo el mundo de acuerdo, y con el que se comercia con todas las regiones de al-Andalus. Cerca de él está el in de Firriš, en el que hay una cantera de un mármol excelente, que toma su

${ }^{151}$ E. Lèvi-Provençal, La peninsule iberique au Moyen Age, 171 de la traducción; Gamal 'Abd al-Karim, "La España musulmana en la obra de Yãquaț", Cuadernos de Historia del Islam,6, (1974), 232. Por el contrario J.M. Carabaza considera que Firriš debía encontrarsen el actual Cerro de Hierro "La producción agrícola del suroeste andalusí", Separata del Boletín de la Asociación Española de Orientalistas, (Madrid 1992), 93.

${ }^{152}$ Al-Himyari, Kitāb Raw al al-Mi'târ, 143 texto árabe y 171-2 de la traducción; Yãquât, Mu'Yam al buldãn, t. IV, 259; 'Abd al-Karim, "La España musulmana", 232.

${ }^{153}$ Al-Idrisi, Los caminos de al-Andalus en el s. XII, (Madrid 1989), 170; Vallvé, J., La división administrativa de la España musulmana, 313-4.

${ }^{154}$ Ibn Hayyăn, Muqtabas, V, 356.

${ }^{155}$ Al-Maqqari, Nafth al-Tibb, t. I, 503.

${ }^{156}$ Al-Idrisi, Kităb nuzhat al-muštă 207 de la edición y 256 de la traducción al francés.

${ }^{157}$ Al-Himyari, Kitāb Rawd al-Mi'tăr, 143.

${ }^{158}$ Ibidem. 
nombre de este in, y el mármol firniši es el mejor blancura, granulado y dureza ${ }^{159}$.

En lo que están de acuerdo todas las fuentes es en la riqueza agrícola del territorio ${ }^{160}$, que producía cereales en gran cantidad, aunque su importancia se debía sobre todo a los árboles, como las higueras, avellanos, cerezos, nogales, almendros y, especialmente, castaños.

Constantina se entregó al rey Fernando III en 1247, durante las operaciones para cercar Sevilla ${ }^{161}$; Firiš parece ser que resistió unos años más, pero en el año $648 \mathrm{H} / 1250$ d.C el señor de Jerez, Abū Jălid, la entregó a los castellanos junto con Arcos y otras fortalezas ${ }^{162}$.

Hay dos personajes de especial relevancia salidos de Firriš. El primero, del mismo Firrī̌s, fue Jalaf b. Yãsìn ${ }^{163}$, tradicionista famoso por sus cualidades que murió en $327 \mathrm{H} /$ 938 d.C., y el segundo de Constantina, el alfaquí Abū Sa'ìd al-Tuŷŷibii ${ }^{164}$, destacado en la corte de Córdoba, que murió en el año 917.

Montellano.

El castillo de Cote ${ }^{165}$, cercano al pueblo de Montellano, fue uno de los numerosos hușūn utilizados en el s.IX por los rebeldes al emirato omeya para declararse en rebeldía. Si bien hay vestigios de anteriores ocupaciones hasta el Neolítico, no conservamos fuentes escritas acerca de su historia hasta esta época, en que Taalib b. Mawlūd el muladí huyó de Córdoba y reconstruyó Hișn Aqūt y el Hișn de Ŷabal al-Hiŷara (entre el año 888 y el 894)166. En el verano del año 895 un general del ejército del príncipe al-Muțarrif le atacó y le obligó a volver a la obediencia:

Se destrozaron las alquerías que rodeaban Hịnn Aquț. Luego preparó Ahmad b. Hāšim a su ejército, y por la mañana ascendieron contra el malvado Tãlib b. Mawtud; (llegaron) a la hora de la oración del mediodía de aquel día, y salió (

\footnotetext{
${ }^{159}$ Al-Idrisi, Kitäb nuzhat al-muštăq, 207.

${ }^{160}$ Carabaza, J.M., "La producción agrícola del suroete andalusí", 93.

${ }^{161}$ Alfonso X, Primera Crónica General, t. II, 749.

${ }^{162}$ Al-Dajira al-saniyya, p. 79.

163 'Abd al-Karim, "La España musulmana", 232; Yãquat, Mu'ŷam al-buldān, t. IV, 259.

${ }^{164}$ Crónica anónima de 'Abd al-Raḥmān III al-Nășir, (Madrid-Granada 1950), 125-6.

${ }^{165}$ Sobre este castillo hay alguna bibliografía: L. Mora Figueroa, "El donjón tetrabsidal del castillo de Cotte (Montellano-Sevilla)", Estudios de Historia y de Arqueología medievales V-VI (1985-6), 391-426; M. García Fernández "La carta puebla del castillo de Cote", Archivo Hispalense 214 (1987), 57-67; J. Pascual Barea, "De Mons Acutus al castillo de Cote (Hișn Aqüt)", Archivo Hispalense, 1995. Tras las excavaciones dirigidas por la Dra. Valor Piachotta en verano de 1998 se espera la publicación de varios trabajos sobre el tema.
}

${ }^{166}$ Al-'Uduri, Tarși' al-ajbār, 114. 
Tãlib) de su Hișn con sus hombres. La batalla se agudizó entre él y los hombres del sultán, y se agudizó y se prolongó hasta el anochecer. Luego se volvió Tãlib y sus compañeros, que fueron derrotados, y murieron setenta de sus hombres. Se apoderaron (los soldados del emirato) de su campo al pie del monte con todo lo que había en él. Se echaron hacia la cumbre del monte y saquearon las gentes del ejército lo que habían abandonado (en la huida). Les vencieron en los baños y en la almunia, que fueron demolidos y quemados. Se refugiaron Tãlib y sus compañeros en Hișn Aqut, y continuaron los derribos, la tala de árboles, el incendio y la destrucción de las alquerías que hay alrededor. Cuando se sometió el malvado Tàlib b. Mawtud y pidió que se le aceptara en la obediencia, se le aceptó.

Poco después le fue arrebatado el Hișn por uno de sus caballeros, Ibn Humayd ${ }^{167}$, que mantuvo una tormentosa alianza con Ibn Hafșūn, que unas veces estaba más próximo al emir de Córdoba y otras al rebelde de Bobastro ${ }^{168}$. En el año 914 'Abd al-Rah mān III construyó el Hișn de Išbera (Espera) contra el de Aqūt, y aprovisionó el de Šilibar. Poco después Cote volvió al control del emirato. No tenemos más menciones de Cote hasta el final del dominio almorávide sobre al-Andalus; en šawwāl del año 538 ( 7 de abril a 5 de mayo de 1144) uno de los primeros rebeldes andalusíes, Abū-l-Qãsim b. Qasī, conquistó Cote, mediante uno de sus subalternos, aunque no pudo mantenerse, pues los almorávides reaccionaron rápido y asaltaron el Hișn antes de que pudiera prepararse ${ }^{169}$.

Cote se entregó a Fernando III en 1240, poco después de la conquista de Córdoba, y fue ocupada por el infante don Enrique durante algún tiempo, aunque en época de Alfonso X pasó a manos de la Orden de Alcántara que construyó la torre que aún hoy puede admirarse. Poco después expulsaron a los andalusíes y los trasladaron a Šilibar. Sabemos que Cote fue atacado por los benimerines ${ }^{170}$ en dos ocasiones (1277 y 1285 ), en la segunda ocasión con consecuencias desastrosas, y poco después quedó despoblado.

\footnotetext{
${ }^{167}$ Al-'Uduri, Kitāb Tarși' al-ajbār, p. 115.

${ }^{168}$ Ibn Hayyân, Al-Muqtabis, V, 114, 172

${ }^{169}$ Ibn al-Jațî, Kitāb A'mal al-a lăm, 248-50. Trad. J.Ramírez.

170 Al-Qabtawri, Rasaill diwăniya min Sabta, 57-58. Aquí se narra el ataque de 1277, que, en un estilo tremendamente complicado, cuenta el ataque. En nuestra opinión no consiguí su objetivo, aunque por el texto no se puede asegurar.
} 